\section{James W. Button}

"Did anybody ever have a superficial conversation with Jim Button?" The pastor's question, posed to a crowded memorial service at the United Church of Gainesville, elicited smiles and vigorous head shaking. At the reception following the service, several graduate students, junior faculty, and staff members volunteered that they attended the service simply because Jim Button had repeatedly gone out of his way to show them friendship and respect. Both the question and the comments caught the essence of Jim Button. To professional colleagues, he was a path-breaking scholar of minority and urban politics, a pioneer in the academic study of gay rights, school-based health clinics, and the political mobilization of senior citizens. But Jim Button was loved and treasured because of his deep passion for his students, family, colleagues, friends, and for those Americans who had been treated unjustly by history and politics.

James W. Button, born in 1942, was raised in the small upstate town of Sodus, New York. A gifted athlete, musician, and prankster, he excelled academically and went on to attend Colgate University, his father's alma mater. On graduating in 1964, he decided to pursue a career in education. He obtained an M.A. in education from Stanford in a program that emphasized active student involvement in the educational process, a lesson that stuck. After teaching secondary school in Sunnyvale, California, he decided that political science was his forte, earning an M.A. at UCLA and beginning doctoral studies at the University of Texas. In 1973, two years before completing his doctorate, he made his way to the University of Florida where he worked for his entire academic career.

A concern for the underdog, a word he would never have used, pervaded all of his scholarship. His wife traced Jim's inspiration to the experience of working alongside the black migrant workers who came to his family's apple-cherry farm each year to pick the fruit. He was impressed, among other things, by how the women worked as hard and at the same tasks as the men. He gained a deep respect for their lives and a strong commitment to producing first-rate scholarship as an effective tool of social change.

His first book, Black Violence: Political Impact of the 1960s Riots (Princeton, 1978), grew out of his NSF-funded dissertation. The book displayed the traits that would recur in Button's subsequent research-specifically, an important substantive research question, a multimode research design, and a provocative answer. The book explored the policy impact of the urban violence in the 1960 s by analyzing the responses of three key federal agencies. He combined systematic quantitative analysis of public data, case studies of selected communities, and depth interviews with key decision-makers, an eclectic mix of approaches that characterized all of his subsequent work. The principal finding, a powerful challenge to conventional wisdom about social change, was that violence worked-to a degree. Virtually every significant allocation decision by federal agencies after the riots was assessed for its effect on the prospect of further urban violence. While these reactions fell far short of promoting deep structural changes to address the poverty and inequality of life in urban America, they nonetheless suggested that policy makers became attentive to the consequences of federal programs for urban social conditions. Lauded by Contemporary Sociology as a "fascinating account of behind-the scenes policy making," the book marked Button as an important voice in the ongoing debate about race and American public life.

Over his career, Button continued to ask whether the political system could address the needs of Black Americans but turned his focus to local politics. Shortly after arriving in Florida, he had begun to monitor political conditions for Blacks in six diverse Florida communities. He visited them periodically, interviewing local leaders and community activists, conducting archival research, and doing what later became known as "soaking and poking." These visits included students as part of a research team. Drawing on these data, his 1989 book, Blacks and Social Change (Princeton), assessed how the political opportunities created by the civil rights movement had affected everyday Black life. What difference had Black empowerment made in terms of basic public services such as fire and police protection and private sector opportunities in housing and employment? In Old South communities where Blacks had long suffered repression and violence at the hands of Whites, Black mobilization was fiercely resisted and succeeded in part because of the actions of the federal gov- ernment and local elites, who feared for social order if Black demands were not addressed. Greater success without as much external support occurred in younger, urban, "New South" communities. In both environments, Black elected officials became critical agents of change, publicizing opportunities that might otherwise have gone unknown in the Black community and recruiting African Americans for various positions in the public sector. While still conscious of the limits to conventional political action, this book was more hopeful about the payoff from non-violent mass mobilization. The Southern Political Science Association honored Blacks and Social Change with the prestigious V. O. Key Book Award.

At the time of his death, he had completed a third book manuscript dealing with race and politics. Race, Affirmative Action and Inter-Minority Competition, coauthored with Barbara Rienzo, looked specifically at the economic consequences of Black empowerment in the same six communities profiled in Blacks and Social Change. The study examines the puzzle of why Black economic achievement lagged so far behind the community's political progress. For this study, he augmented his normal method of data collection by conducting a systematic survey of business owners and managers, combining the interview data with aggregate data on community characteristics. The goal was to provide a fuller picture of "what kinds of jobs blacks are filling, how employers are recruiting and screening applicants, what skills employees need, the ways in which employers view black applicants and how black and white workers are responding to and viewing employment issues." The study also factored in the inter-minority competition for jobs posed by the entry of new immigrants and more White females into the job market, antidiscrimination laws, and affirmative action. Some of the findings have already been published as the lead article in the 2003 volume of Social Science Quarterly. The most surprising finding was the potency of affirmative action: support for the principle of affirmative action by those in charge of personnel decisions made a significant contribution to Black employment success. Echoing a finding from Blacks and Social Change, Black hiring was accentuated when the person responsible for employee recruitment was a woman or member of a racial minority. 
Understanding the Black civil rights movement as a powerful model, Jim also looked carefully at social movements on behalf of other disadvantaged groups. A series of publications coauthored with Walter Rosenbaum looked at the "grey peril" thesis, the claim that intergenerational political conflict would become a dominant motif in urban politics. While largely dismissive of alarmist findings, this research did recognize the potential for age-related political conflict on a subset of issues. The empirical study of gay politics was in its infancy when Jim spearheaded an investigation of this new frontier in civil rights activism. As with his studies of African Americans, Jim wondered whether politics as usual could make a difference in the lives of gay men and lesbians. Once again, he turned to a community analysis for an answer. In Private Lives and Public Conflicts (Congressional Quarterly, 1997), Jim and his two coauthors explored the impact of local laws and policies that prohibited discrimination on the basis of sexual orientation. The principal data for this study was a survey of the nearly 200 communities that had passed such laws (along with a comparison sample of American communities) and case studies of gay rights politics in five particular cities. The book, written jointly with Barbara Rienzo and Ken Wald, demonstrated the impact of such laws on multiple levels. In his introduction to the volume, Congressman Barney Frank of Massachusetts drew from the book the central lesson that conventional politics could work for gay people. Despite their minority status, gays and lesbians found it possible to forge coalitions that passed ameliorative laws that, as the study revealed, produced significant changes in their life chances. Jim took particular pride when the data in the book were widely cited by activists campaigning for local gay rights legislation.

His concern for youth and sexuality prompted Jim to undertake another set of studies about the movement for schoolbased health clinics, institutions that attempted to deliver health care to young people in disadvantaged communities. These institutions were pilloried as "sex clinics" by critics who claimed that providing reproductive services encouraged teen sexual promiscuity. His research agenda sought to identify the factors that both promoted and retarded the effective delivery of health care through these institutions. Resorting to the same design he had used so often in the past, Jim and coauthor Barbara Rienzo surveyed the heads of several hundred clinics and supplemented their inquiry by intensive interviews in five communities. The
Politics of Youth, Sex and Health Care in American Schools, published by Haworth in 2002, provided detailed accounts of these battles, tutoring health care advocates on the pitfalls that faced clinics and suggesting strategies for surmounting them.

As much as he embraced tools such as surveys and aggregate data analysis, Jim believed that research was incomplete without sustained human contact. Although his data came from people, he never reduced people to data, treating all his research sources with respect and dignity. This penchant for face-to-face interviews often called for considerable tact on his part and, on one occasion, for some discretion as Jim and a colleague found their interview with a business owner interrupted by an armed robbery. $\mathrm{He}$ also believed that researchers needed decompress from all that human contact, insisting that a day of field research conclude with a hearty meal, good wine, and a lot of laughter.

His teaching was very much of a piece with his scholarship. Button arrived at the University of Florida via the undergraduate division, known as the University College, where he taught interdisciplinary courses with historians, anthropologists, and sociologists. Many of his closest friendships dated from this experience. Moving into the department of political science a few years later, he maintained his enthusiasm for such courses and infused his political science offerings with diverse perspectives. Apart from handling the survey course in State \& Local Politics, he taught upper division courses on the politics of poverty, minority politics, race, gender and change, and gay and lesbian politics. He also offered the graduate field seminar in Urban Politics.

Over the years, he acquired a reputation as an extraordinary teacher who demanded much of his students but gave back more. Twice named "Teacher of the Year" by various units at the University, Jim Button successfully conveyed his enthusiasm for the subject and created a classroom environment that welcomed spirited discussion, whether politically correct or not. He also knew how to keep a light touch. Confronting a twohour instructional block for the freshman course in state-local politics, he wondered how to keep the course lively for the non-majors who took what was, by reputation, the most boring course in the political science curriculum. Jim hit on the idea of breaking the class at the midpoint with a Chinese-style group exercise session and followed that with a joketelling contest in which he awarded the best story-teller with a small bonus on the next exam. These small gestures enlivened the class and made the students receptive to material they might otherwise have slept through. Similarly, long before "active learning" became a buzzword, he required his students in advanced classes to spend time in organizations related to the subject of study. He also assigned critical reaction papers so students would confront the assigned readings, not merely digest them. Students were also offered positions on his research projects, giving them direct field experience.

Borrowing from Will Rogers, one can say that Jim Button never met a student (or colleague, for that matter) whom he wouldn't mentor. Long lines formed outside his door during office hours and he seldom emerged from his office until late in the day. Beyond providing an opportunity for students to discuss class subjects or politics in general, these conferences often evolved into personal counseling sessions. Students opened up to Jim because of his sincerity and evident concern, telling him their problems, seeking his advice. Minority students, students struggling with personal decisions about sexual orientation, students with troubles of many kinds found in him a warm counselor, ready to help them find their way. Little wonder that he was named "Adviser of the Year" by the College of Arts and Sciences (1990) and statewide "Mentor of the Year" in 1995 by the McKnight Foundation.

Constitutionally incapable of compartmentalizing his life, Jim also promoted social justice through service to the community. He was an elected member of the Community Action Agency in Alachua County and an expert witness on behalf of minority plaintiffs in five federal voting rights lawsuits. He testified in front of local government bodies in support of anti-discrimination legislation and on behalf of benefits for same sex couples. In recognition of his steadfast commitment to improving the world through his research, teaching, and service, the University bestowed on him the President's Humanitarian Award in 2002.

His colleagues in the department of political science frequently called on him to play crucial institutional roles. At various points in his career, Jim was interim department chair, associate chair, undergraduate coordinator, and the chair of more search committees than anybody could remember. In fulfilling these roles, he was a tireless advocate of diversity, pressing his colleagues to expand the department's course offerings in minority politics, recruiting graduate students, and chairing searches for minority faculty hires. 
Lest one imagine that only an ascetic could exhibit such single-minded devotion to social improvement, it's reassuring that Jim possessed a sense of humor that often skirted the edge of good taste and frequently obliterated it altogether. Over the years, he delighted in leaving wickedly obscene messages laced with double entendres on my answering machine, knowing they would prompt me to return his calls more quickly than I would otherwise have done. This sense of humor was in fullest display with his family. During the winter months, Jim regularly tried to warm up his elderly father in snowbound New York by sending a stream of salacious Florida postcards and seldom hesitated to share the cards with his colleagues whether they wanted to see them or not. As much as his father enjoyed receiving these missives, Jim got an even bigger kick out of sending them.

Jim was exceptionally involved with his family. Deeply engaged with sons Matt and Adam Bennett during their childhood in Bloomington, IN, he kept in close touch by letters, phone calls, and frequent visits. As they testified, he gave them enough love for several lifetimes. During his final years, he was delighted as the family circle expanded to encompass his daughters-in-law, Jen and Kathleen. He spent as much time as his health allowed with his grandsons, Max and Ty, visiting them often in Chicago and regaling friends with the photos and stories of the visits. Jim was also the social hub for his extended family of brothers and sisters, frequently hosting them in Florida or visiting them in New York and elsewhere. Following the tragic death of his brother Henry a few years ago, Jim naturally slipped into the role of family counselor.

Jim was fortunate to share his life with Barbara Rienzo, his wife since 1980. Barb was both a partner and research collaborator. Drawing on her academic specialization in health science education, Barb and Jim partnered to offer legendary sex education courses at their church. They offered the students information, honesty, and moral seriousness about human sexuality, receiving in return the gratitude and affection of their students. Jim and Barb also collaborated on the gay rights and affirmative action books.

Jim was a wonderful friend to many of his professional colleagues and fellow members of his church. He loved to dine with friends at raucous lunches and equally fulfilling dinners. As an administrator, he believed in the importance of social activity with colleagues and promoted departmental picnics, parties, and receptions.
For decades, Jim struggled with the pernicious medical condition known as chronic fatigue syndrome. Devastating on its own terms, the disease is even more toxic because so little research and treatment is available. As time passed, the disease grew more potent, the negative periods becoming more frequent, intense, and harder to shake. Jim's life became increasingly circumscribed. Lacking energy, unable to sleep, finding even reading increasingly difficult, he gradually retreated from full-time teaching, postponed research trips, and was facing early retirement. On his last visit to Chicago, he couldn't manage the strength even to play with his grandkids. Faced with the reality that medical science has nothing to offer to relieve his constant pain and exhaustion, Jim chose to end his life.

Losing Jim Button would never be easy because life seldom offers us such gifts of friendship and love. Those of us who worked with him were blessed to know him in life and can best honor his memory by striving to realize his values. His family has offered one way to do that by creating the James Button Scholarship, a needs-based scholarship to be given to a deserving graduate student in political science. Checks made out to the University of Florida Foundation may be sent to The James Button Scholarship Fund, Department of Political Science, POB 117325, University of Florida, Gainesville, FL 32611-7325.

Ken Wald University of Florida

\section{Virginia May Currey}

Virginia May Currey, former Southern Methodist University political science professor, charter member of the Women's Studies Program, and political activist, died of pneumonia on September 22 at the age of 78 .

Ms. Currey was born May 6, 1927, in Gowrie, Iowa. She received her bachelor's degree from the State University of Iowa, a master's degree in international affairs from Columbia University and a doctorate from the University of Iowa. She taught in the Middle East and did research for the CIA before becoming a professor first at the University of Texas at Arlington and then at SMU where she taught for 32 years.

Ms. Currey married Donald P. Currey in 1954. Mr. Currey died of cancer 10 years later, and Ms. Currey raised their three children as a single parent.

While at SMU Currey encouraged her students to run for political office and to work on campaigns. Allan Saxe, a politi- cal analyst and associate professor of political science at the University of Texas at Arlington, said that as an educator and an individual, Ms. Currey left an indelible impression. He said her teaching style influenced his, putting "the classroom in the political marketplace" by taking students to Austin and Washington, D.C., both to observe and participate. She also organized and taught pioneer courses on women in politics and Black politics at a time when those subjects were still viewed with some suspicion. Currey was both a social scientist and a committed activist equally at home in the coolness of academic discourse and in the heat of campaign rhetoric.

Currey was best known in Texas as a member of the State Board of Education from 1976 to 1984 . She was able to successfully fight for eradicating racism and sexism in state-adopted textbooks. "Because of my mother and others like her, textbooks are no longer littered with stereotypes," daughter Ellen Currey-Wilson said.

Currey served as a delegate to the Democratic convention in 1968 and 1972 and was a founding member of the Texas Women's Political Caucus, the National Women's Political Caucus, the National Women's Studies Association, and the Veteran Feminists of America. Currey's work earned her several prestigious awards, including the Wonder Woman award in 1982, which was presented to her by Gloria Steinem, and the Friend of Freedom Award, given by the Americans United for Separation of Church and State.

Currey is survived by her sister, Margaret Paulos of Davenport, Iowa; a brother, John Anderson of Storm Lake, Iowa; two daughters, Ellen Currey-Wilson of Portland, Ore. and Amy Currey of Eugene, Ore.; a son, James Currey of Shady Shores, Texas; and five grandchildren.

\section{Brad Carter Southern Methodist University}

\section{George A. Graham}

George Adams Graham, political scientist and emeritus educator, passed away on February 25, 2005, at his home in Chapel Hill, North Carolina. He was 100. Among Dr. Graham's most lasting achievements will be his work professionalizing and improving governance of the public sector.

On the occasion of his centennial on December 23, 2004, two of his friends unknowingly presented him with the same card, which read: "Wisdom, integrity, wit, compassion-these aren't the virtues of youth. They're qualities earned 
through years of hard choices, brave decisions, bold ideas. And when these qualities are present in a man, others see a life well-lived." Indeed there are many who would acknowledge not only George Graham's well-lived life, but his significant influence on theirs. For his part, Dr. Graham was always quick to acknowledge how much others had helped him along the way.

Congressman David Price (D-NC) writes: "As one who received encouragement from George and had occasional academic exchanges with him (about Woodrow Wilson, mainly), I want you to know how much I admired him. I know that there have been many tributes and expressions of affection from George's friends and admirers, far and wide. I count myself among them."

George Graham was a faculty member in the politics department at Princeton University from 1930 to 1958 . He served as chair from 1946 to 1949 and again from 1952 to 1955. During his tenure at Princeton, he wrote two books, Education for Public Administration in 1941 with Henry Reining, and Morality in American Politics in 1952.

At Professor Graham's memorial service March 3, 2005, in Chapel Hill, former Princeton graduate student Frederic Cleaveland, said, "It is easy to see George fulfilling his role as a supporter and wise counselor of graduate students. I knew him as a seminar leader at Princeton just at the time many of his students had recently returned from World War II. His vision of graduate education in public affairs could be seen in the design of the soon-to-be-established Woodrow Wilson School of Public and International Affairs," which opened in 1948. "He served as one of its principal founders and was committed to developing an interdisciplinary approach to advanced learning that blended science, economics, history, sociology and anthropology, thereby achieving an open curriculum of considerable breadth and depth in the social sciences."

James W. Clark of Princeton, New Jersey, writes: "I had two courses with George when I joined the first Graduate level class of the Woodrow Wilson School at Princeton in 1948. In 19491950 I worked closely with him in producing a management study/administrative history of the Department of the Interior. George was a strong supporter of a career civil service and improved and modern management of the public's business. He was very important in shaping my views, and to this day, I am still working to improve the program at the Woodrow Wilson School in preparing candidates for Public Service. "“
Harry Howe Ransom, Emeritus Professor at Vanderbilt University in Nashville, Tennessee, remembers that:

"George Graham chaired the politics department as I entered graduate school, fresh from the Army. I found Professor Graham to be a teacher of utmost integrity, intellectual toughness, and, importantly to a raw and uncertain graduate student, exceptional kindness."

David Stanley of Arlington, Virginia, says: "From the time I met him as a freshman in Princeton, he was an agreeable and helpful friend. As a professor he was always wise and fun to be with. I liked him from the beginning and carry a lot of affection for him still."

After 28 years at Princeton University, Dr. Graham joined the Ford Foundation from 1956 to 1957 as director of the Public Affairs Program. It was in this capacity that George Esser first met him and remembers Dr. Graham's help in obtaining a \$100,000 grant for the University of North Carolina's Institute of Government. Esser, who was involved in a number of foundation-supported programs on social justice in the south, later went on to become program advisor at the Ford Foundation from 1969-1972.

He remembers Dr. Graham as "a man of quiet leadership who knew his field and was devoted to the values of this country."

In 1958, George Graham moved to the Brookings Institution as director of governmental studies. It was here that he authored his third book, in 1960, called America's Capacity to Govern. He stayed at Brookings until 1967.

Harold Orlans, of Bethesda, Maryland, remembers: "I met George in 1960 when I went to work for him at Brookings. He became and remained my teacher and friend. I learned from him how to survive in Washington and maintain your integrity. He was a good man."

In 1967, George Graham became a founding fellow and the first executive director of the National Academy of Public Administration (NAPA) where he stayed until 1972.

Daniel Skoler of Bethesda, Maryland, writes: "I am a NAPA fellow whom George sponsored many years ago. After my first try failed, he encouraged me to run again and I was elected. Watching his style, decency, wisdom and dedication was always an inspiration and strength to me-a kind of invisible inspiration and mentorship."

Eleanor Futrell of Upper Marlboro, Maryland, says: "I worked for him in the late sixties and early seventies at the National Academy of Public Administration and think he was one of the finest people I have ever worked with. His integrity and incredibly hard work were role models for me and probably contributed to his very long and productive life. "

Charlie Henry from Eugene, Oregon, writes: "George Graham was my chief mentor in pursuing my career aim of public service in local government and I am much indebted to him for his sound guidance and other help. After graduation he steered me into a starting position with Public Administration Service, then of Chicago. With this organization, I worked for over five years as a management consultant seeking to improve the performance of several state, city, and county agencies and the Government of Puerto Rico. Then over the next 27 years, I served as the city manager in three cities. George honored me by having me nominated to the National Academy of Public Administration."

In June 2004, NAPA President C. Morgan Kinghorn and Board Chairman Carl W. Stenberg honored Dr. Graham in Chapel Hill with a Resolution expressing their deepest gratitude and appreciation "for his dedication to the work and mission of the National Academy and commitment to the highest ideals of public service" and for "demonstrating steadfast concern that this nation take every step necessary to ensure a continued strong public service at every level of government."

The Resolution adds that: "George A. Graham was largely responsible for the development of the project panel approach, in which selected Fellows would serve on panels to guide and carry out individual research projects with the assistance of a small project staff, a model that has withstood the test of time and remains one of the hallmarks of the Academy's strong research capacity."

In 1984, after achieving emeritus status at Nova Southeastern University in Fort Lauderdale, Florida, where he was a principal designer of the school's doctoral programs, George Graham concluded his career as professor of public administration. He was 80 years old.

Roy W. Crawley, second executive director of the National Academy of Public Administration, remembers: "What a long and productive life George had during which he enriched so many lives. He and I had a long and unique relationship at Brookings, the Academy, and Nova. He was friend, mentor, critic, and sponsor. His contributions to the field of public administration are unparalleled. In truth, he became a legend and will indeed be missed.

Doug Yoder in Coral Gables, Florida, writes: "George was a teacher, mentor, and colleague to me during the mid1970 s when we were both at Nova 
University. His thoughtful commitment to public management as a profession of the highest importance, has been a sustaining inspiration to me throughout my public service career. His own commitment to his family and friends serves as a testimonial to the values he held so dear and to his commitment to the institutions needed to make those values accessible to all. He bridged many generations, from the New Deal years right up to the present, with insights and grace that enabled him to be a part of each generation-a current participant in society with an unerring sense of history. While he was many years my senior, his wit, vitality, and thoughtful listening easily overcame any sense of a generation gap. In these times in particular, our country and the world needs battalions of George Grahams to sort through all that is happening - to separate the wheat from the chaff, and to act in the public interest, as he did all his life. I guess it remains for those of us who were privileged to count George as a friend and mentor, to serve now in his stead and follow his vision to the future."

George Graham dedicated his life of teaching, research, and public administration to ensuring strong public service at every level of government. This devotion to public service led to a variety of research and administrative positions at the state and federal level, including the Citizens Federal Committee on Education, the Committee on Public Administration of the Social Science Research Council, the U.S. Bureau of the Budget from 1942 to 1945 , the chairmanship of the Hoover Commission Committee on Indian Affairs from 1945 to 1946, the Hoover Commission Committee on Organization of the Executive Branch of Government in 1948 , the Senate Subcommittee on Ethics in Government in 1951, and as staff director for the second Hoover Commission Task Force on Personnel and Civil Service from 1953 to 1954 . Dr. Graham's collection of reports, notes, correspondence, and subject files from his service in most of these assignments may be found at Princeton University.

In 1984, at the age of 80, Dr. Graham retired to Chapel Hill where he later wrote recollections of his life. In 1994, he joined forces with former Brookings scholar Frederic Cleaveland to form the "Plato Loft" group, a bi-weekly discussion forum modeled on Princeton University seminars and composed of former students, colleagues, and retired diplomats. Throughout his life, George

Graham was a firm believer in the power and importance of the group.

Former Senate Staff Director Walter Stults, a member of the Plato Loft group and a former Princeton graduate student, recalls: "Professor Graham was one of two people who chose me to be among the first contingent of World War II Fellows to attend the graduate program at the Woodrow Wilson School in 19481949. He was such a remarkable person whose character and intelligence influenced so many of his friends and students. For those of us who knew George for many years, his continued interest in current events and his lifelong search for answers was an inspiration."

Frederic Cleaveland, who was also professor of public administration at both the University of North Carolina-Chapel Hill and at Duke, adds, "I knew him for more than 50 years as a friend, teacher, and professional colleague. He was always the same gentle and unassuming man-direct and open in his approach to those with whom he was associated. His sincerity, simplicity, honesty, and integrity were so apparent that it attracted attention and support from those around him. As a friend, teacher, and mentor, George continually searched for ways to open new avenues of growth for fellow workers. He helped them expand their ability to master new experiences and thereby become more fulfilled as individuals. Many of us can attest to how George Graham brought us new insights and understanding and we can be profoundly grateful that he has been an important part of our lives."

Born December 23, 1904, in Cambridge, New York, Dr. Graham received his B.A. from Monmouth College (Illinois) in 1926 and a Ph.D. in political science from the University of Illinois (Urbana-Champaign) in 1930. He married Rosanna Grace Webster in 1930. She died in 1985. There is an annual Creative Writing prize awarded in her name at Monmouth College.

Dr. Graham is survived by his second wife, Elisabeth Childs Rowse Graham, daughter of Harwood L. Childs, a member of the Princeton politics department from 1932-1957, who taught its first classes in propaganda and public opinion (following his 1931-1932 fellowship in Germany), and who founded, in 1936, the Public Opinion Quarterly.

Dr. Graham is also survived by two daughters, Lora Graham Lunt of Potsdam, New York, and Mary Graham Jenne of Scarsdale, New York; a daughter-in-law, Martha Dix Graham (wife of son, Andrew Allen Graham, who died in 2001); 6 grandchildren, 4 great grandchildren, 7 step children, and 6 step grandchildren.

Writes Bill Flash of Pittsboro, North Carolina: "I worked and taught in the same field, public administration, and met George at annual professional meetings and later in Chapel Hill. George was always most warm and hospitable to me whenever we did encounter one another. His way of life seemed so much what I would like, not only for his scholarship and writing in our field, but most particularly for George as teacher and colleague, his encouraging human-ness to others and his example as a warm and insightful human being. His very life was a tribute to those qualities he shared with us."

Mary E. Rowse

Washington, D.C.

\section{Marjorie Mowlam}

Marjorie Mowlam, who received her $\mathrm{Ph} . \mathrm{D}$. in political science from the University of Iowa in 1977, died at Pilgrim's Hospice in the United Kingdom on August $19^{\text {th }}$ at age 55 from the recurrence of a brain tumor that had been first diagnosed nine years earlier. In the interval between that diagnosis and her death, she rose to become Britain's most popular politician on the strength of her accomplishment as secretary of state for Northern Ireland in negotiating the Good Friday Accords in 1998. When she subsequently fell from Tony Blair's good graces and was sidelined to the Cabinet Office, her personal popularity only rose further. To Blair's embarrassment, she received a standing ovation at the Labour Party Conference in 1998 in the middle of the prime minister's report to the delegates.

Mo, as she liked to be called, came to the University of Iowa after receiving a B.A. in Anthropology from the University of Durham in the U.K. Her Ph.D. dissertation, on the effect of the referendum on Swiss politics, was a highly creditable piece of research but it hardly presaged her distinguished political career. A recommendation sent by one of her professors at Durham as part of her Iowa application was more prophetic. He wrote that "she had a particular talent for bridge-building between groups .... and there can be no doubt that she contributed a great deal to the general peace and goodwill that prevailed throughout the University [of Durham] during her period [there]."

She was an iconoclast, breaking conventions and challenging orthodoxies, but doing it in such a candid, good humored way that she rarely gave anyone offense. Mo was a lively, enthusiastic, enterprising, and conscientious student who went on to an academic career first at Florida State University and then at the University of Newcastle-Upon-Tyne. But Labour Party politics was her first 
love and when she was given a chance to campaign for the House of Commons in 1987 she could not resist. Her meteoric rise in parliament followed. She became Labour Party spokeswoman for Northern Ireland during her first term, was elected to the Shadow Cabinet in her second, and was appointed to the Cabinet in her third.

Mo returned to the University of Iowa in 1998 to accept its Distinguished Alumni Award and on that occasion gave a talk entitled "People Matter." She tried to relate some general lessons she had learned in political science to the process of negotiation that led to the Good Friday Accords. In a tribute to the many individuals who contributed to those accords, she ended with a quote from Maya Angelou: "History, despite its wrenching pain, cannot be unlived, but if faced with courage, need not be lived again." In politics as in her personal life, she was a woman of remarkable courage.

Gerhard Loewenberg University of Iowa

\section{Whitney T. Perkins}

Once in a long while some of us are blessed to encounter a person whose character is so special that it deeply affects us for the rest of our lives. Such is the case for me-and for many alumni of the Brown University international relations program-with regard to Whitney T. Perkins, the faculty member who guided the program for decades and who died earlier this year. In an academic world filled with pomposity and pretense, he stood out as a beacon of humility. In an academic world filled with ideological polemics, he stood out as a beacon of balance. In an academic world filled with politically motivated jostling for power and control, he stood out as a beacon of integrity. In an academic world filled with self-promotion and hyperbole, he stood out as a beacon of restraint and understatement.

From the moment I first met Whitney when I was interviewing (with my father) to decide if Brown University was the right place for me, through my years studying under him taking every course he offered, ending with the time after he retired when I shared some of my writings with him, he was a constant model of sage and compassionate guidance. Understanding as he did the true meaning of a service profession, his interests were not in attaining personal glory but rather in doing all he could to bring out the best in his students. What he taught us in the classroom about the world was important, but how he taught us was even more vital. I lived for the moment when, after reviewing something I submitted to him, his eyes twinkled with approval.

Now my beacon is gone. But every day I teach, I think about him, trying to the best of my abilities to reflect his timeless wisdom and not to succumb to the temptations of the day. Within the ivory tower I have met nobody like him, and probably never will; all I can do is to treasure his memory and be eternally grateful to have known him.

\section{Bob Mandel Lewis \& Clark College}

\section{John N. Plank}

John N. Plank, professor emeritus of political science, died suddenly at his home in Storrs, Connecticut on April 30, 2005 , at the age of 81 .

A veteran of the North African and European campaigns in the Second World War, John received his A.B. from Harvard in 1949, his M.A. from Haverford in 1953, and his Ph.D. in 1959 from Harvard. At Harvard he was an instructor, assistant professor, and research associate at the Center for International Affairs. In 1962 he became a professor of Latin American Affairs at the Fletcher School of Law and Diplomacy at Tufts University. The following year, John was appointed director of the Office of Research and Analysis for American Republics in the State Department's Bureau of Intelligence and Research, and later received the Superior Honor Award from the Department. From 1964 to 1970, he was a senior fellow at the Brookings Institution, and from 1970 to 1985 he was professor of political science at the University of Connecticut.

John was the editor of Cuba and the United States: Long-Range Perspectives (Brookings, 1967), and he published numerous articles and essays on interAmerican relations in scholarly books and journals as well as to wider audiences in Daedalus, Foreign Affairs, and the New York Times Magazine.

John was involved in numerous professional activities as well. He was president of the Inter-American Council, and a representative to the Senior FulbrightHays Program. Among other associations, John was a member of the Council on Foreign Relations, the Latin American Program Advisory Committee to the School of Advanced International Studies of the Johns Hopkins University, the Faculty Advisory Committee of the National War College, the United States Committee of the Inter-American Association for Democracy and Freedom, and the United Nations Association Panel on Multilateral Alternatives to Unilateral Intervention.

A dedicated Quaker, John directed the American Friends Service Committee (AFSC) Project in Community Development in El Salvador, as well as the AFSC's International Service Division Executive Committee, its Davis House Executive Committee, and its International Affairs Program Executive Committee.

At the University of Connecticut, John taught courses in Latin American politics, inter-American relations, comparative politics, and political theory. His lifelong love of normative political theory infused his teaching, as he impressed on a generation of students the need to combine power with moral purpose.

When John retired in 1985, the University of Connecticut cited him for his scholarship, government and community service, in which he "carved out a notable place for himself as a voice of reason in hemispheric affairs. ... Plank steadily articulated the need for U.S. policy to be formed with an understanding and compassion for the peoples of Latin America." His community service and writing for a general audience reflected John's understanding that a supportive constituency for such policies had to be built.

John's retirement years were spent revisiting the classics of literature and political theory in the several languages he knew, and discovering new ones. He was active in the Storrs Friends Meeting, and he had a wealth of friends and admirers, who were attracted to his gentlemanly ways, his graciousness, and his keen interest in everyone he met.

John N. Plank is survived by his wife of 52 years, Eleanor, his brother Stephen, two sons and a daughter, and many devoted grandchildren, nieces, nephews and friends.

\author{
Howard L. Reiter \\ University of Connecticut
}

